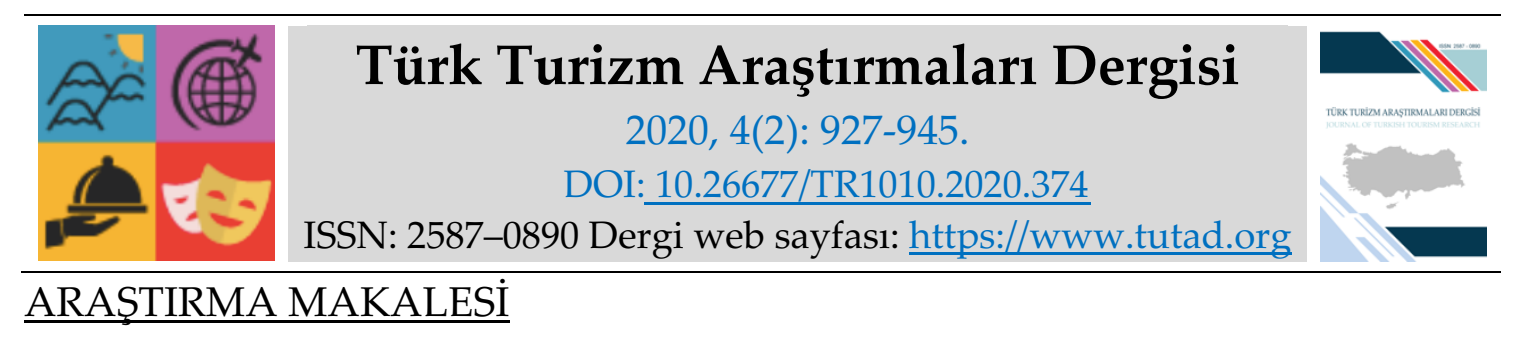

\title{
Yeni Tüketiciler Arasındaki Kuşak Z'nin Tatil Tercihleri: Üniversite Öğrencileri Örneği
}

\author{
Dr. Günseli GÜÇLÜTÜRK BARAN, Bağımsız Araştırmacı, e-posta: gunseli-8148@hotmail.com \\ ORCID: https://orcid.org/0000-0003-2866-459X
}

Dr. Gamze ÖZOĞUL, Dokuz Eylül Üniversitesi, Efes Meslek Yüksekokulu, İzmir, e-posta: gamze ozogul hotmail.com

ORCID: https://orcid.org/0000-0003-1169-5533

Elçin NOYAN, Doktora Öğrencisi Muğla Sıktı Koçman Üniversitesi, Sosyal Bilimler Enstitüsü, Muğla, e-posta: elcinnoyan@hotmail.com

ORCID: https://orcid.org/0000-0003-2630-0274

\section{Öz}

Kuşakların davranış kalıpları, dönemin teknik, kültürel ve ekonomik olaylarına bağlı olarak farklı özelliklere sahiptir. Buna göre üreticiler için farklı bir pazar bölümüne yönelik yeni bir fırsat doğar. Buna rağmen günümüzün yeni turistik tüketicileri arasında yer alan $\mathrm{Z} \mathrm{Kuşağı} \mathrm{ile} \mathrm{ilgili} \mathrm{sınırlı} \mathrm{sayıda} \mathrm{çalışma}$ olduğu anlaşılmaktadır. Buradan hareketle çalışmanın amacı Z Kuşağının tatil tercihlerini belirlemektir. Bu bağlamda nicel çalışma yöntemi temel alınmıştır. Örneklem kapsamında toplam 225 katılımcı verisi analiz edilmiştir. Çalışma sonuçlarına göre Z Kuşağındaki katılımcıların tatil süresini 4-6 gün, turizm türünü kıyı turizmi, konaklama işletmesini otel, yiyecek içecek işletmesini kafe-restoran ve ulaştırma yolunu karayolu bakımından tercih ettiği ve tatilde eğlence işletmesine gitme eğilimleri de olduğu anlaşılmıştır. Bu sonuçlara dayanarak Z Kuşağının genellikle tercih ettiği kıyı turizmi çekim yerlerinde yer alan otel, kafe-restoran, ve eğlence işletmeleri gibi işletmelerin bu kuşağın ilgi ve beklentilerini karşılamak üzere çalışmalar yapması önerilir. Diğer taraftan Z Kuşağı daha çok ailesiyle birlikte tatile gitme ve tatile çıkmadan önce plan yapma eğilimleri gösterirken, ayrıca tatil ücretini kendi karşılamama eğilimindedirler. Kümeleme analizi sonucuna göre toplam üç küme ortaya çıkmıştır. Değişkenler arasından en önemli değişken tatile gidilen kişi tercihi ve en az önemli değişken ise hediyelik eşya işletmelerinden faydalanma tercihidir. Seyahat acentaları ve tur operatörleri bu bilgileri göz önüne alarak pazarlama çalışmaları gerçekleştirebilirler.

Anahtar Kelimeler: Z Kuşağı, Tatil, Tüketici Davranışı, Pazarlama, Profil/Tercih.

Makale Gönderme Tarihi: 17.01.2020

Makale Kabul Tarihi: 08.04.2020

\section{Önerilen Atıf:}

Güçlütürk Baran, G., Özoğul, G. ve Noyan, E. (2020). Yeni Tüketiciler Arasındaki Kuşak Z'nin Tatil Tercihleri: Üniversite Öğrencileri Örneği, Türk Turizm Araştırmaları Dergisi, 4(2): 927-945.

(C) 2020 Türk Turizm Araştırmaları Dergisi. 


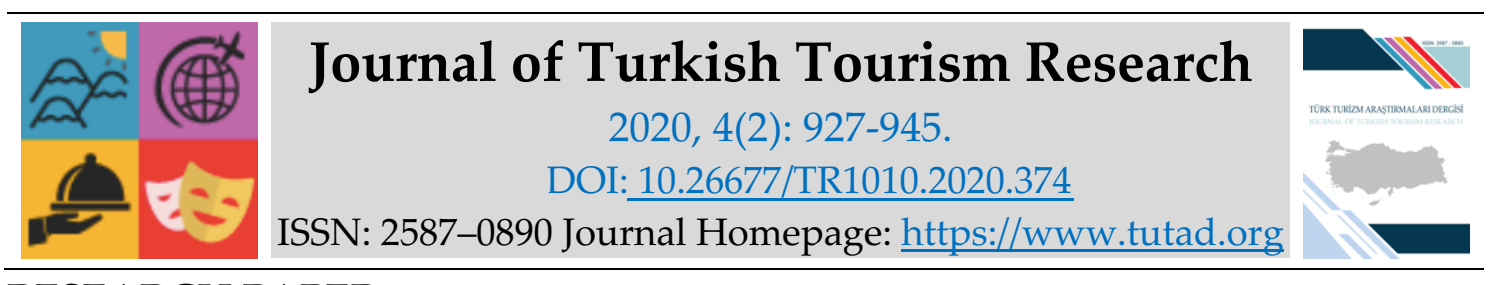

RESEARCH PAPER

\title{
Holiday/Vacation Preferences of the Generation Z among New Consumers: Sample of University Students
}

Dr. Günseli GÜÇLÜTÜRK BARAN, Independent Researcher, e-mail: gunseli-8148@hotmail.com ORCID: https://orcid.org/0000-0003-2866-459X

Dr. Gamze ÖZOĞUL, Dokuz Eylül University, Efes Vocational School, İzmir, e-mail: gamze ozogul hotmail.com

ORCID: https://orcid.org/0000-0003-1169-5533

Elçin NOYAN, PhD. Student, Muğla Sıktı Koçman University, Social Sciences Institute, Muğla, e-mail: elcinnoyan@hotmail.com

ORCID: https://orcid.org/0000-0003-2630-0274

\begin{abstract}
The behavior patterns of generations have different characteristics depending on the technical, cultural and economic events of the period. Accordingly, it arises a new opportunity for a different market segment for producers. Even so, it is understood that there is a limited number of studies on Generation Z, which is among the new tourist consumers of today. In this direction, the aim of this study is to determine the preferences of the Z Generation for holiday. In this context, quantitative research method is based on. A total of 225 participant data were analyzed within the scope of the sample. According to the results of the study, it was understood that the participants in generation $\mathrm{Z}$ preffered 4-6 days as holiday duration, the type of tourism is the coastal tourism, accommodation establishment is the hotel, food and beverage establishment is the café-restaurant, and transportation way is the highway, and also they have tendencies to go to entertainment/recreation establishments. Based on these results, enterprises such as hotels, cafes, restaurants and entertainment entriprises should carry out researches, in order to meet the interests and expectations of this generation in the coastal tourism destinations which are usually preferred by the $\mathrm{Z}$ Generation. It can be stated that the research will fill the gap in the literature by revealing its preferences for meeting the needs of $Z$ Generation and so shedding light on the researchers and practitioners. On the other hand, Gen $\mathrm{Z}$ mostly tends to go on holiday with their family and make plans before going on holiday, also, they tend not to pay the holiday fee themselves. According to the result of cluster analysis, a total of three clusters emerged. Among the variables, the most important variable is the preference of the person to go on holiday and the least important variable is the preference for benefiting from the souvenir enterprises.Travel agencies and tour operators can carry out marketing studies considering this information.
\end{abstract}

Keywords: Generation Z, Holiday/Vacation, Consumer Behaviour, Marketing, Profile/Preference.

Received: 17.01 .2020

Accepted: 08.04.2020

Suggested Citation:

Güçlütürk Baran, G., Özoğul, G. and Noyan, E. (2020). Holiday/Vacation Preferences of the Generation Z among New Consumers: Sample of University Students, Journal of Turkish Tourism Research, 4(2): 927-945.

(C) 2020 Türk Turizm Araştırmaları Dergisi. 


\section{Gíriş}

Kuşak, felsefi anlamda yaklaşık aynı yıllarda doğmuş ve aynı çağın koşullarını paylaşmış ve benzer yükümlülükleri bulunmuş kişilerin topluluğu şeklinde ifade edilirken, toplum bilimi açısından "yaklaşık 25-30 yıllık yaş kümelerini oluşturan birey öbeği, göbek, nesil, batın, jenerasyon" şeklinde tanımlanmaktadır (Türk Dil Kurumu [TDK], 2019). X ve Y Kuşaklarından sonra gelen ve bu çalışmada ele alınan Z kuşağı, 1995-2009 yılları arasında doğan, teknolojiyle etkileşimli özellik gösteren, interneti yoğun kullanan (Yeoman vd., 2012: 20) ve bu bakımdan diğer kuşaklardan ayrılan bir kuşak olarak açıklanmaktadır. Ayrıca fiziksel olanla dijital olan ayrımının ortadan kalktığı ve "fijitalleşme" evriminin ilk kuşağıdır. Z Kuşağı yüz yüze iletişime de önem vermektedir. Onlara ulaşmaya çalışan reklamlar ise onları ikna etmek için daha çok çabaya ihtiyaç duymaktadır. Nitekim Z Kuşağı gerçekçi, hırslı, bağımsız, sürekli bağlantıda olan, aşırı kişileştirmeden yana olmakla beraber paylaşım ekonomisi ile sorunlara yaklaşan, "kaçırma korkusu" duyan, "biz ekonomici" ve "kendin yap"çı temel özellikleriyle ortaya çıkmaktadır (Stillman ve Stillman, 2018).

Z Kuşağı günümüzün yeni çalışanlarını ve yeni tüketicilerini oluşturmaktadır. Demografinin ise gelecekteki turizm talebi için kilit bir faktör (Yeoman vd., 2013: 91) olacağı öngörüsü ve turizmin gelecekteki büyümesinde endüstrinin gezgin davranışını etkileyen sosyal ve demografik eğilimlerin iyi anlaşılmasıyla şekilleneceği (Moscardo vd., 2010) gibi görüşler kuşak çalışmalarına da zemin hazırlamakta ve önemli bilgiler sağlanmasını olanaklı kılmaktadır. Tüm bu bilgiler göz önüne alındığında turistik tüketici tercihlerinin incelenmesi, tüketicilere yönelik belirli bir genel çerçeve oluşturmaktadır. Bu bakımdan Z Kuşağının tatile yönelik tercihlerinin belirlenmesi, pazarlama ve tüketici davranışı alanına ışık tutması açısından önemlidir. Örneğin pazarlamada kullanılan internet tabanlı uygulamalar ve bu uygulamalarda (web sitelerinde, kişiye özel e-mail ile bilgilendirme vb.) öne çıkan ürün ve unsurlar tercihlere göre şekillenmekte, hatta kıyaslamaya da olanak tanımaktadır. Bu gibi uygulamalar için çalışma sonuçlarının tüketicilere yönelik düzenlemelere de katkı sağlayacağ ${ }_{1}$ söylenebilir. Diğer bir katkı ise otel gibi turizm işletmelerinin sözgelimi aileleriyle veya arkadaşlarıyla deniz-kum-güneş için tatil yapanlara, diğer bir ifadeyle günümüzün $\mathrm{Z}$ Kuşağı olan gençlere yönelik konaklama seçeneklerinde ve çocuklu olmayan ailelere yönelik ayrı içerikler sağlanmasında profesyonel alana yönelik birtakım katkılar sağlaması mümkündür. Bunun yanında ulaştırma+yiyecek-içecek+bölgesel turlar+konaklama içeren paket turların ortaya çıkarılmasında çalışmada belirlenen tercihler göz önüne alınabilir. Teorik açıdan turizm endüstrisinde $Z$ Kuşağının daha anlaşılır kılınması bakımından bu konudaki çalışmaların ise arttırılması önemlidir ve çalışmanın diğer bir katkısı bu yöndedir.

Çalışmada öncelikle Z Kuşağı hakkında kuramsal çerçeve çizilerek çalışma yöntemi açıklanmıştır. Ardından $\mathrm{Z}$ Kuşağı tatil tercihleri belirlenmeye çalışılmıştır. Bu doğrultuda $Z$ Kuşağının konaklama, ulaştırma ve yiyecek-içecek işletmesi tercihleri, rehberli tur, eğlence ve hediyelik eşya işletmelerinden faydalanma durumu, tatil sürelerinin ne sıklıkta olduğu, kimlerle tatile gitmeyi daha çok tercih ettikleri ve ne tür turizm faaliyetine katılmayı seçtikleri ile ilgili sorulara yanıt aranmıştır. Aynı zamanda bu tercihler kümeleme analiziyle önem derecesine göre sıralanmıştır. Ayrıca çalışmada elde edilen sonuçlar ile alanyazında kuşak konusundaki mevcut çalışma sonuçları birbiriyle kıyaslanmıştır.

\section{LITERATÜR TARAMASI VE KURAMSAL ÇERÇEVE}

Aynı yaş gruplarına hitap eden ürünlerin sunulmasında tüketici davranışlarını belirlemek önemlidir (Bezgin, 2016: i). Bu hususta kuşak kavramı ortaya çıkmaktadır. Dünyada ekonomik ve sosyal hareketlere bağlı olarak ayrılan zaman aralıklarına kuşak denilmektedir. Her kuşağın 
kendi döneminde kendine özgü kültürel kodları, değerleri ve davranış kalıpları bulunmaktadır (Kırık ve Köyüstü, 2018: 1497). Nitekim her kuşağın satın alma davranışlarını etkileyen benzersiz beklentileri, deneyimleri, yaşam tarzları, değerleri ve demografileri vardır. Bunun nedenleri olarak kuşak tarihini şekillendiren, ekonomi, bilimsel ilerleme, politika, teknoloji, suikast ya da terör saldırıları gibi sosyal şok içeren olay ve gelişmelerin ardından çok büyük etkilerin hissedilmesidir (Williams ve Page, 2011: 48).

Bu çalışmanın konusu Z Kuşağı turistik tüketici profilinin belirlenmesine yöneliktir. Çalışmanın teorik dayanağı, Kuşak Teorisi'dir. Karl Mannheim (1952) tarafından öne çıkarılan Kuşak Teorisi, Strauss ve Howe (1991: 113-295; 1997: 37) tarafından sosyal ve tarihsel olaylara göre özellikle 1700 'lü yıllardan itibaren beş döngüde ve yaklaşık yirmi yıllık sürelere göre kuşakların ayrılmasına dayanmaktadır. Nitekim Bandura'nın (1977; 2001) 1960'lı yıllarda çalışmalarına başladığı Sosyal Bilişsel Teorisi ve Sosyal Öğrenme Teorisi (çevre, sosyal olaylar ve davranış ilişkisini öne çıkarır), Erikson’un (1963; 1968) Psikososyal Teorisi (Yaşam döngüsünü yaş, tutum, değer, inanç sistemi ve fiziksel çevreyi içeren değişkenlerle aşamalara ayırır ve bu yönde insan gelişimini ele alır) gibi teorilere dayalı olarak politik, sosyal ve ekonomik kapsamda ortaya çıkan önemli olaylar bir toplumun değer sistemini ve kişiliğini değiştirebilmektedir (Chen ve Shoemaker, 2014). Schewe ve Meredith (2004) yaklaşık 17-23 yıl aralığında bir kuşağın benzer dışsal olayları deneyimlemesi sonucu benzer tutum, davranış ve değerlere sahip olmasına yol açtığını belirtmektedir. Ancak araştırmacılara göre farklı parametrelerin göz önüne alınması da söz konusudur (Glenn, 1977; Pilcher, 1994; Donnison, 2007). Bu hususta kuşakların tanımlanmasına yönelik belirli bir zamanda meydana gelen olaylardan hangilerinin önemli olarak tanımlanacağı, hangi doğum yıllarının kronolojik açıdan gruplandırılacağı ve hangi grupların kuşak kavramını ifade edebileceği gibi parametreler tartışmaya açık kalsa da genellikle kuşakların zamansal/tarihsel ve olaylara göre ayrımının birbirinden çok farklı olmadığ anlaşılmaktadır. Bu kapsamda günümüzde yaşayan kuşaklar Sessiz (Geleneksel) Kuşak (19251942), Bebek Patlaması Kuşağı (1943-1960), X Kuşağı (1961-1981), Y Kuşağı (1981-1995) (Strauss ve Howe, 1991: 8), Z Kuşağı (1995-2009) ve Alfa Kuşağ1 (2010) (McCrindle ve Wolfinger, 2009: 199-202) olarak öne çıkmaktadır.

Kuşaklar üzerinde yapılan çalışmalar teorinin geliştirilmesi yanında pratik kararları da destekleyebilmektedir. Kuşaklar, yalnız teorik bir mesele olarak görülmeyerek nesiller arasındaki yaklaşımın nasıl olabileceğine de ş̧ık tutmaktadır (Törőcsik vd., 2014: 23). Kuşak Teorisi, yalnız "bir doğrunun/gerçeğin" kabul edilmesinin tersine rakip ya da kyyaslanabilir örneklerin varlığından hareket etmektedir. Teori, kuşakları içeren dönemleri doğum yılı temelinde gruplara ayırarak bu grupların karakteristik özelliklerinin anlaşılmasını tanımlar. Başka bir ifadeyle bireysel odaklanma yerine geniş fırça darbesi (broad brush-stroke) yaklaşımından hareket eder. Öncelikle Amerika'da ortaya çıkarılan bu teoriye göre bir kuşağın üyeleri, kuşağının özelliklerinden kabaca tahmin edilebilir sınırlar içinde kronolojik açıdan etkilenen, gelişen ve yeniden tanımlanandır. Örneğin bir taraftan internet tabanlı bilgi iletişim teknoloji sistemlerinin ve uygulamalarının kullanımı gibi gelişmeler, diğer taraftan bu gelişmeler içerisinde deneyimlerin, aynı yeri, inancı ve değerleri paylaşan insanların o kuşağın özelliklerini kolektif şekilde biçimlendirmesidir. Kuşak Teorisi üzerine verilebilecek diğer bir örnek ise 2008 yılında yaşanan dünya finansal krizi Y Kuşağının işlerini kaybetmelerine, kredilerini ödeyememelerine veya işyerlerini kapatmalarına yol açmıştır. Bu durumlar bir arada değerlendirilirse, $Y$ Kuşağının öncelikli değerleri "güvenlik" olarak ortaya çıkmakta ve yeteneklerinin ise bilişim sistemlerine göre değişmesiyle kendini göstermektedir (Pendergast, 2010: 1-8).

Z Kuşağının genel karakteristik özellikleri ise aşağıdaki gibi sıralanabilir (Wood, 2013; Dolot, 2018: 46; Kırık ve Köyüstü, 2018: 1513): 
- Teknolojiyi diğer kuşaklara göre çok daha iyi kullanan Z kuşağı, giyilebilir ve taşınabilir teknoloji ürünlerini de günlük hayatının bir parçası hâline getirmiştir.

- İnterneti, özellikle sosyal medyayı kullanan Z Kuşağı, farklı şeyleri "sevmeye", gerçeklik hakkında yorum yapmaya, satın aldıkları ve kullandıkları, nerede nasıl zaman harcadıkları gibi değerlendirmelerde bulunmaya alı̧̧mış bir kuşaktır.

- Z Kuşağı geri bildirim verdikleri gibi, aynı zamanda geri bildirim almayı da beklerler. Diğer bir ifadeyle çift yönlü iletişim algılarlar. Bu durum onların yaptıkları hataları da öğrenme yolları arasında yer alır.

- Sorunlar karşısında pratik çözümler üretirler.

- Özgüven sahibidirler.

- Kendini iyi organize eden bir kuşaktır.

- Hem eğitim alıp hem de çalışma hayatında yer alabilirler.

- İnovasyon odaklıdırlar.

- Hayatı kolaylaştıran şeylerde israrcıdırlar.

- Ekonomik kriz dönemlerini deneyimlemeleri sonucu güvenliğe önem verirler.

- Bir kaçış yaşama (spor yapma, eğlenme, internet aracilığıyla sosyal ağ vb.) eğilimdedirler.

Pazarlamacılar açısından günümüzdeki kuşaklar göz önüne alınırsa yeni ve çoklu nesil pazarlama ile karşı karşıya oldukları belirtilebilir ve işletmeler bu çoklu kuşağın ihtiyaçlarına karşılık vermek durumundadırlar (Williams ve Page, 2011, 48). Bu çalışmanın odak noktasını oluşturan Z Kuşağı, sözgelimi teknolojiye bağlı olmakla birlikte yalnız sosyal medyayı sosyalleşmek için kullanan kişiler değillerdir. Aynı zamanda araştırma ve iş birliği yapmak için sosyal medyayı kullanırken bu ortamdaki tutumlarının yüz yüze iletişimden çok da farklı davranışlar oluşturmayan bir kuşaktır (Sarıoğlu ve Özgen, 2018, 1067). Diğer taraftan Z Kuşağının dijital alışkanlıkları, özçekim yayınlamaları, keşfetmeyi macera ile birleştirmeleri, yeni şeyleri deneyimlemeye açık olmaları gibi birtakım özellikleri diğer kuşaklara göre daha belirgindir (Sima, 2016: 471; Haddouche ve Salomone, 2018: 69). Z Kuşağı boş zamanlarını seyahate çıkarak geçirirler. Konaklama tercihlerinde uluslararası markalar yerine yerel markaları tercih ederler. Lise ve lisans eğitimi alan $Z$ Kuşağı otel işletmelerinde daha çok temizliğe ve güvenliğe önem verirler (Wiastuti vd., 2020: 1). Z Kuşağının seyahat deneyimlerine yönelik özellikleri ise destinasyon merkezli ve bireye yakın olan yerleri seçmeleri (Robinson ve Schänzel, 2019: 127) gibi sıralanabilir. Ayrıca Z Kuşağı içerisindeki akıllı turistler (smart tourists) rahat bir kuşak olmakla beraber kaşif olma özellikleri göstermekte ve tatil satın alma karar sürecinde de teknolojiden büyük ölçüde yararlanmaktadır. Daha bireysel hareket eden Z Kuşağına mensup turistler, seyahat acentalarının uyguladıkları kurallardan dolayı seyahat acentalarını uygun bir tercih olarak görmezler (Kusmayadi vd., 2017). Bu doğrultuda demografik değişikliklerin turizmi doğrudan veya dolaylı olarak etkileyebildiği anlaşılmaktadır (Grimm vd., 2009: 2-5). Dolayısıyla demografi gelecekteki turizm talebi için kilit bir faktördür (Yeoman vd., 2013: 91). Turizmin gelecekteki büyümesi bir dereceye kadar endüstrinin gezgin davranışını etkileyen sosyal ve demografik eğilimlerin ne kadar iyi anlaşıldığına bağlı olarak şekilleneceği belirtilmektedir (Moscardo vd., 2010). Tüm bu bilgiler göz önüne alındığında turistik tüketici tercihlerinin incelenmesi, tüketicilere yönelik belirli bir genel çerçeve, diğer bir ifadeyle profil çizilmesine yardımcı olmaktadır. Bu anlamda turistik tüketici tercihlerinin anlaşılması, pazar bölümlendirmesine önemli bilgiler sunarak, turizm işletmelerinin hedef kitleleri ve alt 
bölümlerinin ihtiyaçlarını karşılayabilecek nitelikte ürün tasarımı gerçekleştirebilmelerini sağlamaktadır. Bu doğrultuda alanyazında kuşakların turizm deneyimleri, tutumları ve seyahat davranış özellikleri bakımından ele alınması gerekliliği de vurgulanmaktadır (Benckendorff vd., 2010).

Özellikle kuşaklararası farklılıklar (Reeves ve Oh, 2007: 296), benzerlikler, kuşaklara ait belirgin özellikler, değerler, beklentiler, alışkanlıklar, ihtiyaçlar veya tercihler (Williams ve Page, 2011: 37; Chiang vd., 2014: 78; Florya, 2014: 1) gibi bilgilerin ortaya çlkarılması turizm endüstrisinde önemli bir yer tutmaktadır. Alanyazında turizm alanında kuşakların (Li vd., 2013: 147; Gardiner vd., 2014: 705) incelendiği çalışmalar mevcutken Z Kuşağı özelinde ise yapılmış çalışmaların daha sınırlı kaldığı (Venter vd., 2015: 2; Sá, 2017: ii; Tavares vd., 2018: 223) anlaşılmaktadır. Dolayısıyla bu çalışmanın amacı, pazar bölümlendirmesine yönelik bilgi sağlanması, Z Kuşağının daha iyi anlaşılması sonucu ihtiyaçlarının karşılanması ve elde edilen çalışma sonuçlarından hareketle uygulayıcılara fayda sağlanması ve alanyazındaki boşluğun doldurulması motivasyonuyla tatile yönelik Z Kuşağının profilinin belirlenmesidir. Bu kapsam çalışmayı önemli kılmaktadır.

\section{YÖNTEM}

Çalışma, kavramsal ve kuramsal açılamalara yer verilerek uygulamalı olarak gerçekleştirilmiştir. Aynı zamanda betimsel-tarama tipinde tasarlanmıştır. Çalışmada amaca uygun olarak aşağıda sıralanan problemlere yanıt aranmaktadır.

- Z Kuşağı tarafından en çok tercih edilen ulaştırma türü, yiyecek-içecek işletmesi ve konaklama işletmesi hangileridir?

- Z Kuşağı tarafından eğlence işletmelerinden faydalanma durumu ne kadardır?

- Z Kuşağı tarafından rehberli tur organizasyonuna katılma durumu ne kadardır?

- Z Kuşağı tatil planı yapar mı?

- Z Kuşağının tatilde hediyelik eşya satın alma durumu nedir?

- Z Kuşağı en fazla hangi turizm türünü tercih etmektedir?

- Z Kuşağının tatile ayırdığı süre ve kendi bütçesinden tatil ücretini karşılama durumu nedir?

- Z Kuşağı genellikle tatile kimlerle gider?

-Z Kuşağının tatil tercihleri kapsamında kaç küme vardır?

-Z Kuşağının tatil tercihlerinin kümelere göre önem sırası nedir?

\section{Anakütle ve Örneklem Seçme Yöntemi}

Çalışmanın anakütlesi, Türkiye' de üniversite öğrenimi gören Z Kuşağıdır. Anakütlenin geniş bir dağılım göstermesi ve anakütleye ulaşmanın zor olması nedeniyle örneklemeye gidilmiştir. Çalışmanın örneklemi, Dokuz Eylül Üniversitesi Efes Meslek Yüksekokulu önlisans öğrencileri (240 birim) ve Muğla Sıtkı Koçman Üniversitesi Fethiye İşletme Fakültesi lisans öğrencileridir (1500 birim). Tesadüfi olmayan örnekleme yöntemlerinden kolayda örnekleme yöntemi kullanılmıştır. Ayrıca örneklemede bazı kriterler temel alınmıştır. Katılımcıların tatil deneyimine sahip olma kriteri bunlardan biridir. Diğer bir kriter ise 18 yaşını doldurmuş olmaktır. Bu kapsamda katılımcıların tatil deneyimine sahip olma durumuna yönelik soruya verilen yanıtlar arasında toplam 27 katılımcının daha önce tatile gitmediği belirlenmiştir. Doğum yılı kriteri 
bazında ise 1995-2009 yılları arasında doğan Z Kuşağı içerisinde 18 yaşını doldurmamış kişiler örnekleme dahil edilmemiştir. Başka bir ifadeyle 1995-2000 yılları arasında doğmuş olmak örneklemede temel teşkil etmiştir.

Örneklem büyüklüğü hesaplamada farklı yöntemler kullanılmıştır. Genellikle 200 birimin yeterli ve 300 birimin iyi/yeterli şeklinde değerlendirilmesi (Comrey ve Lee, 1992: 217; Tabachnick ve Fidell, 2019: 404); madde oranı ile örneklem büyüklüğü hesaplamada ise madde başına en az on veya en az beş birimin yeterli olabileceği göz önüne alınarak 225 kişinin anakütleyi temsil yeterliliğine sahip olduğu varsayılabilir. Nitekim anakütlenin özelliklerinin açıklanmaya çalışılması parametreyi tanımlamaktadır. Anakütlenin örneklem büyüklüğünü temsil edebilmesinde çok sayıda temsili olmayan örneklemin elde edilmesinin etki değerini aşan bir duruma yol açabilmesinin eleştirilmesi de söz konusudur. Bu hususta örneğin temsili olan 100 kişiye ulaşmanın daha önemli olduğu da belirtilmektedir (Nunnaly, 1978; Streiner, 1994, MacCallum, Browne ve Sugawara, 1996, Sapnas ve Zeller, 2002, Karasar, 2008; O’Rourke ve Hatcher, 2013, Garson, 2008, Field, 2009). Ayrıca yukarıda örneklemede ele alınan kriterlerin de örneklem sayısı üzerinde etkisi olduğu söylenebilir.

\section{Veri Toplama Tekniği}

Çalışmada birincil ve ikincil veri kaynaklarından faydalanılmıştır. İkincil veri kaynakları, konuyla ilgili önceki çalışmaları elde etmeye yönelik alanyazın taramasına dayanmaktadır. Birincil veri kaynağı ise nicel verilerdir. Bu doğrultuda Aralık 2018 tarihlerinde Z Kuşağına mensup katılımcılar ile ön görüşmeler yapılmıştır. Katılımcılardan soru formunu incelemeleri istenmiştir. Soru formunda anlaşılmayan soru veya yapılabilecek düzeltme belirtilmemesi üzerine uygulama aşaması Ocak ayında başlamış ve Şubat 2019'da sonlandırılmıştır. Veriler iki bölümden oluşan bir soru formu (anket tekniği) aracılığıyla elde edilmiştir. Soru formu yüzyüze uygulanmıştır. Dolayısıyla tüm katılımcıların herhangi bir soru sorma olasılığına karşın anında soruların yanıtlanmasını sağlamak mümkün hale getirilmiştir. Böylece katılımcı yanıtlarının gerçeği yansıtması için çaba gösterilmiştir. Ayrıca soru formu ile ilgili herhangi bir düzeltme önerisi yöneltilmemiştir. Anket tekniğinin, kısa sürede fazla kişiye ulaşma olanağı sunması ve aynı tür soruların sorulmasını sağlaması, bu tekniğin seçilmesinde etkili olmuştur.

Soru formunda çalışma amacına uygun demografik bilgiler kapsamında doğum yılı ve cinsiyet bilgileri olmak üzere iki soru birinci bölümü oluşturmaktadır. Soru formunun ikinci bölümünde, öncelikle daha önce tatile gitme durumunun tespit edilmesine ilişkin bir soru yer almaktadır. Dolayısıyla tatil deneyimine sahip katılımclar tatil tercihlerinin belirlenmesine yönelik yer alan soruları yanıtlamışlardır. Aynı zamanda daha önce tatil deneyimi yaşamayan katılımcı verileri analiz sürecine alınmamıştır. İkinci bölümdeki sorular toplam 11 adettir. Sorular, Z Kuşağının tatillerinde genellikle hangi turizm türünü, ulaştırma yolunu, konaklama işletmesi türünü, yiyecek içecek işletmesi türünü tercih ettikleri gibi ve tatile genellikle kimlerle gitmeyi, tatilde ne kadar süre geçirmeyi tercih ettiklerine yönelik sorulardan oluşmaktadır. Bu sorular örneğin, "Tatile genellikle kimlerle gidersiniz?", "Genellikle hangi turizm türüne katılmayı tercih edersiniz?", “Tatile çıkmadan belirli bir süre önce plan yapar mısınız?" şeklinde oluşturulmuştur. Yanıtlar çoktan seçmeli, kapalı uçlu (yapılandırılmış) olmak üzere ilgili soruların altında sunulmuştur. Örneğin, "Tatile genellikle kimlerle gidersiniz?" sorusu altında toplam beş seçenek yer almıştır. Bunlar: aile, bireysel, arkadaş/arkadaş grubu, akraba ve diğer şeklinde sıralanmıştır. Birden fazla seçeneğin işaretlenmesine izin verilmemiştir. Sorular oluşturulurken farklı örneklemlerde alışkanlık, profil ve tercih konularını ele alan Asanbekova, (2007: 75-76), Harman (2013: 289-293), Setiawan ve arkadaşlarının (2018: 6-7) çalışmaları 
incelenmiştir. Buradan hareketle bu çalışmanın amacına uygun olacak şekilde sorular geliştirilmiştir.

\section{Analiz Yöntemi}

Nicel araştırma desenindeki çalışmada elde edilen veriler SPSS 20 paket programı aracıllğıyla analiz edilmiştir. Katılımcıların tatil tercihlerine göre benzerlikleri veya farklılıklarının belirlenmesi amacıyla frekans ve yüzde dağılımları ele alınmıştır. Aynı zamanda bu, araştırmanın sınırlılığını oluşturmaktadır. Nitekim profil belirlemeye yönelik değişkenlerin genellikle kategorik olması (bu çalışmada turizm türü, konaklama türü vb.) parametrik/parametrik olmayan test koşullarını da sağlamamaktadır (Hopkins vd., 2018: 654). Ancak bir grup insan belli bir anketin sorularına verdikleri yanıtlara göre sınıflandırılabilirler ve araştırmacı belli bir tip yanıtın diğerlerine kıyasla daha sık ortaya çıkıp çıkmayacağını belirlemek isteyebilir (Bircan vd., 2003:71). Diğer bir sınırlılık ise örneklem seçme yöntemidir. Her ne kadar liste şeklinde öğrenci listelerine ve dolayısıyla bir örneklem sayısına ulaşılabilse de önlisans ve lisans öğrencilerinin hepsinin devam durumu ve çalışmaya katılmaya gönüllü olma durumu göz önüne alındığında kolayda örnekleme yöntemi en uygun yöntem olarak ortaya çıkmaktadır.

Çalışmada kullanılan analiz yöntemlerinden bir diğeri kümeleme (cluster analysis) analizidir. Veri madenciliğinde kullanılan ilk tekniklerden biri olan kümeleme analizi, veriler arasındaki benzerlikleri bulma ve benzer veri nesnelerini ayrık ve homojen gruplar oluşturma işlemi olarak tanımlanır. Veri madenciliği yöntemlerinden biri olan kümeleme analizi pazar araştırması, makine öğrenimi, biyoinformatik, görüntü işleme, kalıp tanıma, veri sıkıştırma, bilgisayar grafikleri gibi alanlarda kullanılmaktadır (Han vd. 2012). Kümeleme algoritmaları, hiyerarşik (aşamalı) ve hiyerarşik olmayan kümeleme tekniği olmak üzere iki başlık altında toplanmıştır (Blashfield ve Aldenferder, 1978, 271-295; Uslu vd., 2017: 20-37).

Hiyerarşik kümeleme yönteminde, gruplayıcı ve bölücü olmak üzere iki yöntem vardır. Hiyerarşik olmayan kümeleme yönteminde ise her birim başlangıçta bir küme olarak kabul edilir. Daha sonra en yakın iki küme yeni bir kümede birleştirilir. Böylece her adımda küme sayısı bir azaltılır. Oluşan küme yapıları, "dendogram" veya ağaç grafiği ile gösterilebilir (Johnson ve Wichern, 2002). Hiyerarşik olmayan kümeleme tekniklerinde küme sayısı bilinmektedir.

İki aşamalı kümeleme yöntemi büyük veri setlerine uygulanabilir. Dolayısıyla kategorik ve sürekli değişkenler işlenebilmekle beraber otomatik olarak en uygun küme sayısı belirlenebilmekte ve elde edilen kümelerle uyum sağlamayan gözlemler gözlem dışında tutabilmektedir. İki aşamalı kümeleme analizinde, süreç ön kümeleme ve kümeleme olmak üzere iki aşamadan oluşmaktadır (Rundle vd., 2015, 522-537; Tkaczynski, 2017, 109-125).

Çalışmada katılımcıların tatile gitme tercihlerinin saptanmasına yönelik verdikleri yanıtlar yönünden her bir grubun her bir değişken açısından özellikleri gözönünde bulundurulmaktadır. İlgili bölümlendirmeyi yaparken değişkenlerin önemlilik düzeyleri de dikkate alınmaktadır.

\section{BULGULAR}

Bulgular, demografik özelliklerle ilgili bilgiler, Z Kuşağı tatil tercihine yönelik bulgular ve kümeleme analizi sonucu elde edilen bulgular olmak üzere aşağıda açıklanmıştır. 


\section{Demografik Bilgiler}

Katılımcların cinsiyete ve yaşa göre demografik bilgileri Tablo 1'de ve Tablo 2'de gösterilmiştir. Katılımciların çoğunluğu $(\% 28,4) 20$ yaşındaki bireylerden meydana gelmektedir.

Tablo 1. Katılımcıların Yaşlarına Göre Dağılımı

\begin{tabular}{|l|l|l|l|l|}
\hline Yaş & Frekans & Yüzde & Geçerli Yüzde & Birikimsel Yüzde \\
\hline 23 & 25 & 11,1 & 11,1 & 11,1 \\
\hline 22 & 39 & 17,3 & 17,3 & 28,4 \\
\hline 21 & 42 & 18,7 & 18,7 & 47,1 \\
\hline 20 & 64 & 28,4 & 28,4 & 75,6 \\
\hline 19 & 41 & 18,2 & 18,2 & 93,8 \\
\hline 18 & 5 & 2,2 & 2,2 & 96 \\
\hline 24 & 9 & 4 & 4 & 100 \\
\hline Toplam & 225 & 100 & 100 & \\
\hline
\end{tabular}

Yaşı en az frekansa sahip 18 yaşında ve 24 yaşındaki katılımcılardır. Ayrıca 19-23 yaş aralığında ise dağılım yoğunlaşmaktadır.

Tablo 2. Katılımcıların Cinsiyete Göre Dağılımı

\begin{tabular}{|c|c|c|c|c|}
\hline Cinsiyet & Frekans & Yüzde & Geçerli Yüzde & Birikimsel Yüzde \\
\hline Kadın & 105 & 46,7 & 46,7 & 46,7 \\
\hline Erkek & 120 & 53,3 & 53,3 & 100 \\
\hline Toplam & 225 & 100 & 100 & \\
\hline
\end{tabular}

Cinsiyete göre katılımcıların birbirine yakın oranı oluşturduğu gözlenmektedir. Katılımcıların $\% 46,7^{\prime}$ si kadınlardan ve $\% 53,3$ 'ü erkeklerden oluşmaktadır.

\section{Z Kuşağı Tatil Tercihine Yönelik Bulgular}

Z Kuşağının tatil tercihleri kapsamlı olarak Tablo 3'te açıklanmıştır. Buna göre tatile birlikte gidilen kişi tercihinde aile en fazla sıklıkta $(n=107)$ yer almaktadır. Bunu arkadaşlarla tatile gitme tercihi izlemektedir. Z Kuşağının tatil ücretini kendi karşılamayanların karşılayanlara göre oranının daha yüksek olduğu, tercih edilen tatil süresinin ağırlıkla 4-6 gün aralığında yer aldığı, turizm türleri arasından \%66,2 oranla en fazla kıyı turizminin tercih edildiği, konaklama 
işletmeleri arasından \%50,2 ile otel işletmesi tercihinin öne çıktığı ve ulaştırma yolu bakımından ise $\% 84$ oran ile karayolunun tatil için kullanıldığ

Tablo 3. Z Kuşağının Tatil Tercihleri

\begin{tabular}{|c|c|c|}
\hline Tatile Birlikte Gidilen Kişi Tercihi & Frekans & Yüzde \\
\hline Aile & 107 & 47,6 \\
\hline Bireysel & 27 & 12 \\
\hline Arkadaş & 81 & 36 \\
\hline Akraba & 6 & 2,7 \\
\hline Diğer & 4 & 1,8 \\
\hline Toplam & 225 & 100 \\
\hline $\begin{array}{l}\text { Tatil Ücretini Kendi Karşılama } \\
\text { Durumu }\end{array}$ & Frekans & Yüzde \\
\hline Evet & 89 & 39,6 \\
\hline Hayır & 136 & 60,4 \\
\hline Toplam & 225 & 100 \\
\hline Tercih Edilen Tatil Süresi & Frekans & Yüzde \\
\hline 1-3 Gün & 37 & 16,4 \\
\hline 4-6 Gün & 97 & 43,1 \\
\hline 7-9 Gün & 43 & 19,1 \\
\hline $10>$ & 48 & 21,3 \\
\hline Toplam & 225 & 100 \\
\hline Tercih Edilen Turizm Türü & Frekans & Yüzde \\
\hline Kiy1 Turizmi & 149 & 66,2 \\
\hline Macera turizmi & 22 & 9,8 \\
\hline Kirsal Turizm & 12 & 5,3 \\
\hline Kültür Turizmi & 14 & 6,2 \\
\hline Sağlık Turizmi & 4 & 1,8 \\
\hline Kış Turizmi & 4 & 1,8 \\
\hline Spor Turizmi & 12 & 5,3 \\
\hline İnanç Turizmi & 5 & 2,2 \\
\hline Diğer & 3 & 1,3 \\
\hline Toplam & 225 & 100 \\
\hline Tatilde Konaklama Tercihi & Frekans & Yüzde \\
\hline Otel & 113 & 50,2 \\
\hline Motel & 4 & 1,8 \\
\hline Tatil köyü & 23 & 10,2 \\
\hline Kruvaziyer & 11 & 4,9 \\
\hline Pansiyon & 19 & 8,4 \\
\hline Kamp & 40 & 17,8 \\
\hline Arkadaş/ Akraba Evi & 12 & 5,3 \\
\hline Diğer & 3 & 1,3 \\
\hline Toplam & 225 & 100 \\
\hline Tatil için Ulaştırma Yolu Tercihi & Frekans & Yüzde \\
\hline
\end{tabular}




\begin{tabular}{|c|c|c|}
\hline Karayolu & 189 & 84 \\
\hline Demiryolu & 5 & 2,2 \\
\hline Denizyolu & 1 & 0,4 \\
\hline Havayolu & 30 & 13,3 \\
\hline Toplam & 225 & 100 \\
\hline $\begin{array}{l}\text { Tatile Gitmeden Önce Plan Yapma } \\
\text { Durumu }\end{array}$ & Frekans & Yüzde \\
\hline Evet & 197 & 87,6 \\
\hline Hayır & 28 & 12,4 \\
\hline Toplam & 225 & 100 \\
\hline $\begin{array}{l}\text { Tatilde Yiyecek İçecek İşletmesi } \\
\text { Tercihi }\end{array}$ & Frekans & Yüzde \\
\hline Kafe-Restoran & 91 & 40,4 \\
\hline Lokanta & 15 & 6,7 \\
\hline Restoran & 35 & 15,6 \\
\hline Konaklama İşletmesinde & 46 & 20,4 \\
\hline Sokak Satıcıları & 21 & 9,3 \\
\hline Diğer & 17 & 7,6 \\
\hline Toplam & 225 & 100 \\
\hline 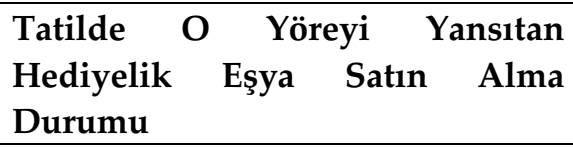 & Frekans & Yüzde \\
\hline Evet & 166 & 73,8 \\
\hline Hayır & 59 & 26,2 \\
\hline Toplam & 225 & 100 \\
\hline $\begin{array}{l}\text { Tatil Yerinde Eğlence İşletmesine } \\
\text { Gitme Durumu }\end{array}$ & Frekans & Yüzde \\
\hline Evet & 187 & 83,1 \\
\hline Hayır & 38 & 16,9 \\
\hline Toplam & 225 & 100 \\
\hline $\begin{array}{l}\text { Tatilde Rehberli Turlara Katılma } \\
\text { Durumu/Rehberli Organize Tur } \\
\text { Kapsamında Tatile Çıkma Tercihi }\end{array}$ & Frekans & Yüzde \\
\hline Evet & 105 & 46,7 \\
\hline Hayır & 120 & 53,3 \\
\hline Toplam & 225 & 100 \\
\hline
\end{tabular}

Z Kuşağı tatile gitmeden önce genellikle $(\% 87,6)$ plan yaparken katılımcıların yaklaşık \%40'1 kaferestoran işletmelerinde yiyecek içecek ihtiyacını karşılamaktadır. Ayrıca tatilde o yöreyi yansıtan hediyelik eşya satın alan Z Kuşağı oranı \%73,8 iken \%83,1'i tatil yerinde eğlence işletmelerinden de faydalanmaktadır. Diğer taraftan Z Kuşağının tatilde rehberli turlara katılma veya tatile rehberli turlar kapsamında gerçekleştirme durumlarının birbirine yakın oranları oluşturmasına karşın rehberli turları tercih etmeme durumu $(\% 53,3)$ tercih etme durumuna $(\% 46,7)$ göre daha yüksektir. 


\section{Kümeleme Aanalizi Bulguları}

İki Aşamalı Kümeleme Analizi kullanılarak yapılan çalışmada model özetlenirse, iki aşamalı algoritma kullanılması sonucu 12 girdi değişkeni için toplam üç küme ortaya çıkmıştır. Tablo 4 'te ortaya çıkan üç kümede yer alan değişkenlerin önemlilik yüzdeleri gösterilmektedir.

Tablo 4. Değişkenlerin Kümelere Göre Önemlilik Yüzdeleri

\begin{tabular}{|l|c|c|c|}
\hline & 1. Küme & 2. Küme & 3. Küme \\
\hline Toplam Sayı & 111 & 61 & 53 \\
\hline Yüzde (\%) & 27,1 & 49,3 & 23,6 \\
\hline Cinsiyet & 51,4 & 82 & 69,8 \\
\hline Eğlence İşletmesi & 87,4 & 80,3 & 77,4 \\
\hline Hediyelik Eşya İşletmesi & 80,2 & 55,7 & 81,1 \\
\hline Kimlerle Tatile Gidildiği & 62,2 & 78,7 & 71,7 \\
\hline Konaklama & 65,8 & 41 & 49,1 \\
\hline Tatil Planı Yapma & 92,8 & 82 & 83 \\
\hline Rehberli Tur Tercihi & 74,8 & 59 & 98,1 \\
\hline Tatil Süresi & 42,3 & 47,5 & 39,6 \\
\hline Turizm Türü & 83,8 & 50,8 & 47,2 \\
\hline Tatil Ücretini Karşıılama & 80,2 & 83,6 & 69,8 \\
\hline Durumu & 81,1 & 86,9 & 86,8 \\
\hline Ulaşım & 36 & 32,8 & 58,5 \\
\hline Yiyecek-İçecek & & & \\
\hline
\end{tabular}

Katılımclar açısından cinsiyet değişkeni her üç küme için de önemlidir (erkekler \%82). Her üç kümenin de analizde yer alan değişkenler açısından önem gösterdiği de belirtilebilir. Kümelere göre değişkenlerin dağılımında tatilde eğlence işletmelerine gitme tercihi (1. Küme=\%87,4), tatilde hediyelik eşyalar satın alma tercihi (3. Küme $=\% 81,1)$, frekans analizi sonucuna kıyasla burada katılımciların tatile arkadaşlarıyla gitmenin tercih edilmesi (2. Küme=\%78,7), konaklama işletmesi olarak otel işletmesi tercihi $(1$. Küme $=\% 65,8)$, tatil öncesi plan yapma durumunun bulunması (1. Küme=\%92,8), tatilde rehberli turlara ihtiyaç duyulması (3. Küme=\%98,1), tatil için ortalama 4-6 gün sürenin tercih edilmesi (2. Küme=\%47,5), kıyı turizmi tercihi (1. Küme=\%83,8), tatil ücretini başkalarının karşılama durumunun olması (2. Küme= \%83,6), ulaşım olarak karayolunun tercih edilmesi $(2$. Küme $=\% 86,9)$ ve yemek yenilen yer olarak restoranların tercih edilmesi $(3$. Küme $=\% 58,5)$ en sık karşılaşılan tercihler olarak öne çıkmaktadır.

Küme büyüklüklerine bakıldığında, 1 . Kümenin \%27,1, 2. Kümenin \%49,3 ve 3. Kümenin \%23,6 büyüklüklük gösterdiği belirlenmiştir. Şekil 1 'de gösterildiği üzere her üç küme üzerinde değişkenler önem derecesine göre sıralandığında en önemli değişkenin tatile gidilen kişi tercihi olduğu anlaşılmaktadır. 


\section{Predictor Importance}

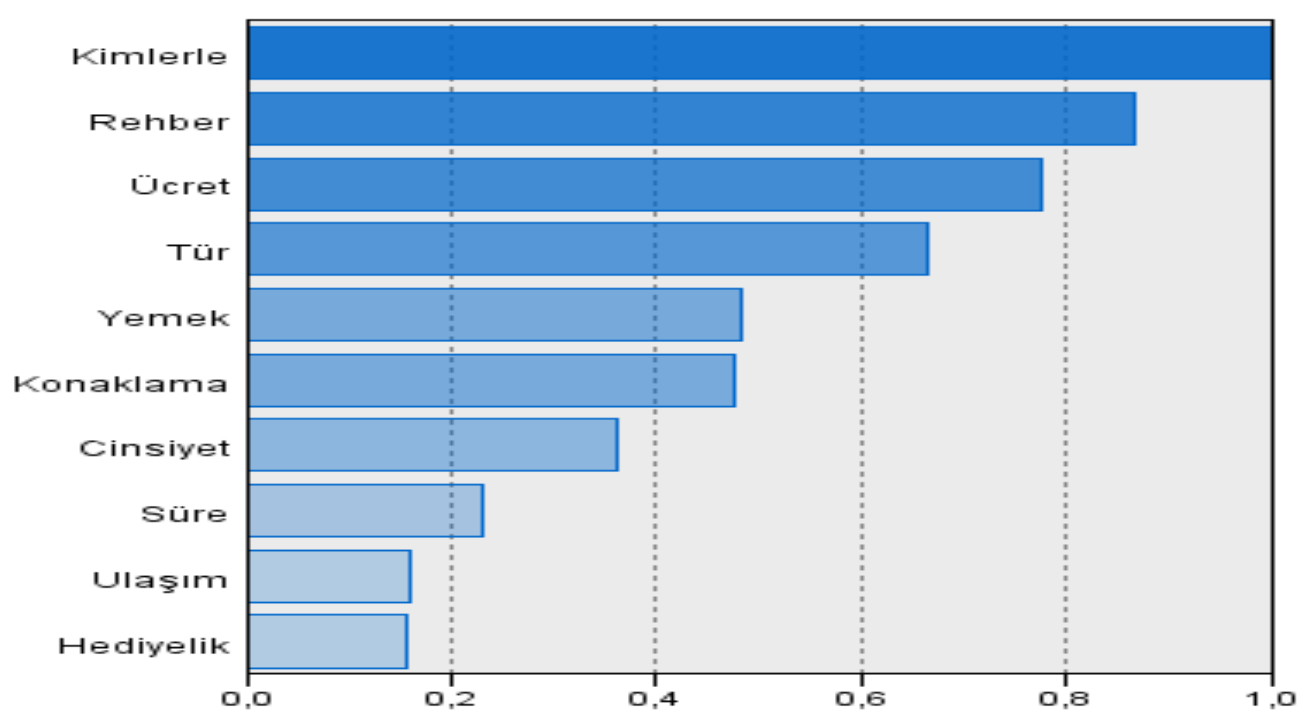

Least Important

Most Important

Şekil 1. Değişkenlerin Önem Dereceleri

Sırasıyla öne çıkan değişkenlerin ise tatilde rehberli turların tercih edilmesi ve tatil ücretinin karşılanma durumu olduğu görülmektedir. En az önemli değişken ise hediyelik eşya işletmelerinden faydalanma tercihidir.

\section{TARTIŞMA, SONUÇ VE ÖNERILER}

Çalışmanın teorik dayanağı, Kuşak Teorisi'dir. Strauss ve Howe (1991: 113-295; 1997: 37) Kuşak Teorisi'nde kuşakları birbirinden ayırmaya yarayan önemli tarihsel, politik ve diğer olayları ortaya çıkarmıştır. Dolayısıyla kuşakların sahip olduğu genel özellikleri ve farklılıkları birer tüketici olarak davranışları üzerinde de farklılık yaratmaktadır. Sözgelimi Z Kuşağının dijital alışkanlıkları, özçekim yayınlamaları, keşfetmeyi macera ile birleştirmeleri, yeni şeyleri deneyimlemeye daha açık olmaları gibi birtakım özellikleri diğer kuşaklara göre daha belirgin (Sima, 2016: 471; Haddouche ve Salomone, 2018: 69) ortaya çımaktadır.

$\mathrm{Bu}$ çalışmanın amacı Z Kuşağının tatil tercihlerinin belirlenmesidir. Çalışma amacına yönelik Fethiye İşletme Fakültesi'nde ve Selçuk Efes Meslek Yüksekokulu'nda anket tekniğiyle Z Kuşağ1 içerisinde yer alan, 18 yaşını doldurmuş 252 katılımcıdan veri elde edilmesi sonucu geçerli görülen 225 katılımcı verisi analiz edilmiştir. Çalışma sonucuna göre Z Kuşağı, genel olarak otelde konaklama, kafe-restoranda yiyecek içecek ihtiyacını karşılama, karayoluyla ulaşım sağlama, ailesiyle birlikte tatile gitme, tatil ücretini kendi karşılamama, tatile çıkmadan önce plan yaparak tatil için 4-6 gün gibi bir süre ayırma, kıyı turizmine katılma, hem tatil yerinde eğlence işletmelerine gitme hem de o yöreyi yansıtan hediyelik eşya satın alma tercihinde bulunurken 
rehberli turlara katılmama oranının ise rehberli turlara katılmaya kıyasla daha düşük bir oranı oluşturduğu anlaşılmaktadır.

Çalışmanın bu sonuçlarına göre lokantaların tatil yörelerinde neden fazla tercih edilmediği bir tartışma konusudur. Tanıtımlarında eksiklik olma durumlarının ya da turistik tüketiciye uzak veya cadde üzeri gibi merkezi alanlarda yer almama durumlarının mı buna etki eden bir faktör olduğu düşünülmelidir. Nitekim tatil yerlerinde yöresel yemeklerin sunulduğu lokantaların yer alması kültür tanıtımında ve aktarımında olumlu çıtılar sunacaktır. Karayolunun daha özgür seyahat etmek isteyen veya farklı yerleri ziyaret etmeyi arzulayan Z Kuşağı için iyi bir seçenek olarak görüldüğü anlaşılmaktadır. Aynı zamanda örneklem kapsamında öğrenim gören $Z$ Kuşağının genellikle çalışmadığı veya çalışsa da birikimini kendi ihtiyaçlarına harcaması söz konusu olabilir (Setiawan vd., 2018: 10). Tatil ücretini kendilerinin ödememesi bu hususta dikkat çekmektedir. Rehberli turlara az sıklıkta katılma tercihi iki yönden incelenebilir. Eğer Z Kuşağının tarihi kültürel bilgi elde etme isteği varsa buna internet yoluyla ulaşabilmesi, bir tur programından bağımsız, daha özgür bir tatil anlayışının ve/ya kıyı turizminde daha çok dinlenme ve eğlenme motivasyonlarının etkisinin söz konusu olabilmesidir. Teknolojik uygulamaların Z Kuşağının ihtiyaçlarını karşılayacak ve merak uyandıracak şekilde düzenlenmesi önemlidir. Sözgelimi, farklı unsurları barındıran müzeler açllabilir. Müzelerde ve ören yerlerinde ise arttırılmış ve sanal gerçeklik uygulamaları bir arada kullanılarak tarihi kültürel bilgiler sunulabilir.

Pazarlama faaliyetlerine bilgi sağlaması açısından özellikle karayolu ulaştırma işletmeleri, otel işletmeleri, kafeler, rehberli tur organize eden seyahat acentaları, deniz/kıyı turizmi çekim yerleri hakkında Z Kuşağının beklentilerinin ayrıntılı şekilde analiz etmeleri gerekmektedir. Diğer taraftan Z kuşağının planlı tatil davranışı göstermeleri ve tatil süresinin 4-6 gün aralığında daha fazla tercih edilmesine bağlı olarak bu süre aralığına yönelik farklı çekim yeri seçenekleri sunulmalıdır. Hediyelik eşya mağazalarından en fazla satılan ürünlerin belirlenmesi ve eğlence ile boş zaman faaliyetlerinden daha çok nelerin tercih edildiğinin araştırılması ise bu ürünlere/faaliyetlere benzer ürünlerin/faaliyetlerin geliştirilmesini olanaklı kılar. Sözgelimi, hediyelik eşya bakımından mıknatıslı süsler gibi ürünlerin mi, yoksa yöresel yiyecek içecek veya halı gibi ürünlerin mi tercih edildiği belirlenebilir. Buna yönelik kooperatif, sanat sokağı veya yiyecek stantlarının organize edildiği bir sokak hizmete açılarak yerli halka da iş kolu yaratılabilir. Boş zaman veya eğlence faaliyetleri arasında gece kulüpleri, sportif faaliyetler, temalı park hizmeti, bilgisayar oyunu vb. tercih durumu da ele alınabilir. Nitekim Z Kuşağı bireysel seyahatten çok aile veya arkadaşlarıyla seyahat etmeyi yeğlemektedir. Bu da ekonomik anlamda harcama kalemlerini arttırarak turizm gelirlerine de etki etmektedir. Bu bakımdan Z kuşağının harcama durumlarının ele alınabileceği de ileri sürülebilir. Bu çalışma sonucunu, kümeleme analizi sonucunda ortaya çıkan en önemli değişkenin tatile gidilen kişi tercihi olması da destekler niteliktedir. En az önemli değişkenin hediyelik eşya işletmelerinden faydalanma olduğu göz önüne alınırsa hediyelik eşya sektörü için çalışmaların arttırılması gerektiği söylenebilir. Ayrıca turizm endüstrisinde katılımcıların öncelikli ihtiyaçlarına göre bir sıralamanın ortaya çıktığı belirtilebilir. Örneğin, katılımcılar tarafından tatile gidilen kişi tercihi, rehberli turlara katılma tercihi ve tatil ücretini karşılama durumu tatil davranışında öncelikli olarak dikkate alınan değişkenlerdir. Bu üç değişken birlikte değerlendirildiğinde, rehberli turların bireysel tatil anlayışına göre genellikle daha ekonomik olması, tatil ücretini ise katılımcının kendi karşılama durumu yanında tatile birlikte gidilen kişilerin (aile veya arkadaş) bir arada ele alınabilmesi tatilin daha çok ekonomik bir faaliyet olup olmama durumuna (veya faydacı özelliklere) göre şekillendiğine işaret etmektedir.

Bu çalışma sonuçları; Tavares ve çalışma arkadaşlarının (2018: 223) çalışma sonucuyla paralel olarak Z Kuşağının deniz/kıyı turizmini tercih ettiği yönündedir. Aynı zamanda farklı 
çalışmalarda (Güney Ege Kalkınma Ajansı [GEKA], 2015: 31; Boz ve Yıldırım Saçılık, 2018: 73) ortaya çıan farklı milliyet ve yaş aralıklarından turistik tüketicilerin deniz-kum-güneş turizmine daha fazla yönelmesiyle tutarlılık göstermektedir. Konaklama işletmelerinden otellerin tercih edilmesi Buffa (2015: 14050) ile Setiawan ve çalışma arkadaşlarının (2018: 7) çalışma sonucuyla örtüşürken rehberli turlara ilgi gösterilmesi sonucu bakımından ise bu çalışma sonucundan ayrılmaktadır. Ulaşım bakımından Z Kuşağının daha çok karayoluna yönelme davranışı göstermesi, Günal'ın (2005: 59) çalışmasında Bebek Patlaması ve X Kuşağı örnekleminden elde edilen sonuçlarla tutarlıdır.

Z Kuşağından tatile birlikte gidilen kişilerin, kadınlar açısından daha çok aileleriyle ve erkekler açısından ise arkadaşlarıyla olması bakımından başka bir çalışma sonucunda Bebek Patlaması ve X Kuşağını oluşturanlar arasında kadınların aileleriyle ve erkeklerin arkadaşlarıyla tatile çıkmaları (Günal, 2005: 59) bu kuşaklarla ortak tercihleri bulunduğunu göstermektedir. Başka bir çalışma sonucuna göre Z Kuşağının diğer kuşaklara göre alışverişe genellikle ailesiyle gittiği, bir ürün satın alırken en çok fiyatına dikkat ettiği, aynı zamanda internet üzerinden alışverişe de ağırlık verdikleri ortaya çıkarılmıştır (Sarı ve Harta, 2018: 970-977). Bu bakımdan Z kuşağı için tüm bilgilerin bir arada değerlendirilmesi profilleri hakkında önem göstermektedir.

Önceden belirtildiği üzere çalışma kapsamında amaç, incelenen örneklem ve analiz yöntemi birer kısıtlılık/sınırlılık ortaya çıkarmaktadır. Bu yüzden farklı analiz yöntemleriyle ve örneklemler üzerinde çalışmaların yapılması kuşkusuz fayda sağlayacaktır. Turizmde Z Kuşağı tercihleri üzerine çalışacak araştırmacılara, yaşanılan yer bakımından bölgesel farklılık gösterme durumu, en sık gitmeyi tercih ettikleri destinasyonlar arasındaki farklılık durumu ve Z Kuşağının kendi içerisinde yaş, cinsiyet vb. bilgilerine göre tutum ve davranışlarındaki farklılıklaşma durumu birlikte ele alınabilir.

\section{KAYNAKÇA}

Asanbekova, G. (2007). Tüketici Davranışı Çerçevesinde Türkiye'yi Ziyaret Eden Rus Turistlerin Tüketim Alışkanlıkları. Yayımlanmamış Yüksek Lisans Tezi, Balıkesir Üniversitesi Sosyal Bilimler Enstitüsü, Balıkesir.

Bandura, A. (1977). Social Learning Theory. Englewood Cliffs, N.J.: Prentice-Hall.

Bandura, A. (2001). Social Cognitive Theory: An Agentic Perspective, Annual Review of Psychology, 52: $1-26$.

Benckendorff, P., Moscardo, G. and Pendergast, D. (2010). Tourism and Generation Y. Cambridge: CABI International.

Bezgin, L. (2016). X, Y, Z Kuşağı Tüketicilerinin Yeniden Satın Alma Kararı Üzerinde Algılanan Marka Denkliği Öğelerinin Etki Düzeyi Farklllıklarının Nörogörüntüleme Tekniklerinden Elektroensefalografi (Eeg) ve Göz İzleme Yöntemleriyle Belirlenmesine Dair Deneysel Bir Çalışma. Yayımlanmamış Yüksek Lisans Tezi, T.C. Hitit Üniversitesi Sosyal Bilimler Enstitüsü, Çorum.

Bircan, H., Karagöz, Y. ve Kasapoğlu, Y. (2003). Ki-Kare ve Kolmogorov Smirnov Uygunluk Testlerinin Simulasyon ile Elde Edilen Veriler Üzerinde Karşılaştırılması, C.Ü. İktisadi ve İdari Bilimler Dergisi, 4(1): 69-80.

Blashfield, R. K. and Aldenferder, M. S. (1978). The literature on cluster analysis. Multivariate Behavioral Research, 13, 271-295. 
Boz, M. ve Yıldırım Saçlık, M. (2018). Kırsal Turizm Gelişiminde Turist Tipolojisinin Seyahat Alışkanlıkları Açısından Belirlenmesi: Çeşitli Turist Grupları Üzerine Karşılaştırmalı Bir Araştırma, Uluslararası Sosyal ve Ekonomik Bilimler Dergisi, 8(1): 60-74.

Buffa, F. (2015). Young Tourists and Sustainability. Profiles, Attitudes, and Implications for Destination Strategies, Sustainability, 7: 14042-14062.

Chen, C. S. and Shoemaker, S. (2014). Age and Cohort Effects: The American Senior Tourism Market, Annals of Tourism Research, 48, September: 58-75.

Chiang, L., Manthiou, A., Tang, J. S., Shin, J. and Morrison, A. (2014). A Comparative Study of Generational Preferences for Trip-Planning Resources: A Case Study of International Tourists to Shanghai, Journal of Quality Assurance in Hospitality \& Tourism, 15(1): 78-99.

Comrey, A. L. and Lee, H. B. (1992). A First Course in Factor Analysis. New Jersey, NJ: Hillsdale Erlbaum.

Dolot, A. (2018). The characteristic of Generation Z, e-mentor, 2(74): 44-50, [Online] http://dx.doi.org/10.15219/em74.1351 [Erişim Tarihi: 19.03.2020].

Donnison, S. (2007). Unpacking the Millennials: A Cautionary Tale for Teacher Education. Australian Journal of Teacher Education, 32(3):1-13.

Erikson, E. H. (1963). Childhood and Society. London: Paladin Grafton Books.

Erikson, E. H. (1968). Identity Youth and Crisis. United States of America: W. W. Norton \& Company Ltd. Inc.

Field, A. (2009). Discovering Statistics using SPSS. 3. Edition. Thousand Oaks, CA: SAGE.

Florya, Y. (2014). Three Generations Travel Saimaa Holiday Oravi. Unpublished Bachelor's Thesis, MAMK University of Applied Sciences.

Gardiner, S., Grace, D. and King, C. (2014). The Generation Effect: The Future of Domestic Tourism in Australia, Journal of Travel Research, 53(6): 705-720.

Garson, D. G. (2008). Factor Analysis. How Many Cases Do I Need to Do Factor Analysis? [Online] http://tx.liberal.ntu.edu.tw/ PurpleWoo/Literature/!DataAnalysis/Factor\%20Analysistypes.htm. [Erişim Tarihi: 25.10.2017].

Glenn, N. D. (1977). Cohort Analysis. Series: Qualitative Applications in the Social Sciences. Newbury Park: SAGE University Press.

Grimm, B., Lohmann, K., Heinsohn, K., Richter, C. and Metzler, D. (2009). The Impact of Demographic Change on Tourism and Conclusions for Tourism Policy at a Glance, Institute for Tourism and Recreational Research in Northern Europe, N.I.T. [Online] https://www.tourismgeneris.com/_res/file/3305/49/0/0907_GermanMinistryOfEconomics_DemographicChange.pdf. [Erişim Tarihi: 29.01.2020].

Günal, V. (2005). Mardin İline Gelen Yerli Turistlerin Profil ve Turistik Davranışlarını Belirlemeye Yönelik Bir Araştırma, Coğrafi Bilimler Dergisi, 3(2): 55-67.

GEKA, Güney Ege Kalkınma Ajansı. (2015). Kuşadası Turizminin Yeniden Pazarlama Stratejisi Projesi Tanıtım Planı, [Online] http://geka.gov.tr/Dosyalar/o_1adq4asmu9re10b71qc3kihp8c8.pdf. [Erişim Tarihi: 10.02.2019].

Haddouche, H. and Salomone, C. (2018). Generation Z and The Tourist Experience: Tourist Stories and Use of Social Networks, Journal of Tourism Futures, 4(1): 69-79. 
Han, J., Kamber, M. and Pei, J. (2012). Data Mining Concepts and Techniques. Waltham, USA: Morgan Kaufmann Publishers Inc.

Harman, S. (2013). Bağımsız Seyahat Eden Yerli Gezginlerin Profili ve Seyahat Alışkanlıkları Üzerine Bir Araştırma, Turkish Studies- International Periodical For The Languages, Literature and History of Turkish or Turkic, 8(6): 279-297.

Hopkins, S., Dettori, R. J. and Chapman, R. J. (2018). Parametric and Nonparametric Tests in Spine Research: Why Do They Matter?, Global Spine Journal, 8(6): 652-654.

Howe, N. and Strauss, W. (1997). The Fourth Turning: What the Cycles of History Tell Us About America's Next Rendezvous with Destiny. New York: Broadway Books.

Johnson, R. and Wichern, D. (2002). Applied Multivariate Statistical Analysis. New Jersey: PrenticeHall.

Karasar, N. (2008). Bilimsel Araştırma Yöntemi. 18. Baskı, Ankara: Nobel Yayın Dağıtım.

Kırık, M. A. ve Köyüstü, S. (2018). Z Kuşağı Konusunda Yapılmış Tezlerin İçerik Analizi Yöntemiyle İncelenmesi, Gümüşhane Üniversitesi İletişim Fakültesi Elektronik Dergisi, 6(2), 14971518.

Kusmayadi, Wiweka, K., Kurniawati, R. and Andyana, I N. (2017). The profile and behavior of "SMART TOURIST" (Generation Z) in travel decision making. 4th World Research Summit for Tourism and Hospitality, pp: 1-13. December 8-11. Orlando, USA. [Online] https://www.academia.edu/37991555/The_profile_and_behavior_of_SMART_TOURIST_Genera tion_Z_in_travel_decision_making [Erişim Tarihi: 18.03.2010].

Li, X., Li, X. R. and Hudson, S. (2013). The Application of Generational Theory to Tourism Consumer Behavior: An American Perspective, Tourism Management, 37(C): 147-164.

MacCallum, C., R., Browne, W. M. and Sugawara, M. H. (1996). Power Analysis and Determination of Sample Size for Covariance Structure Modeling. Psychological Methods, I (2), 130149.

Mannheim, K. (1952). The Problem of Generations. In P. Kecskemeti (Editor), Karl Mannheim: Essays on the Sociology of Knowledge (pp. 276-322). London: Routledge.

McCrindle, M. and Wolfinger, E. (2009). The ABC of XYZ: Understanding the Global Generations. Sydney, Australia: A UNSW Press Ltd.

Moscardo, G., Murphy, L. and Benckendorff, P. (2010). Generation Y and Travel Future, In I. Yeoman, C. Hsu, C. Smith and S. Watson (Eds.), Tourism and Demography (pp.87-100). Oxford: Goodfellow Publishers.

Nunnaly, J. C. (1978). Psychometric Theory. 2. Edition, NewYork: McGrawHill.

O'Rourke, N. and Hatcher, L. (2013). A Step-by-Step Approach to Using SAS® for Factor Analysis and Structural Equation Modeling. 2. Edition, Cary, North Carolina, USA: SAS Institute Inc.

Pendergast, D. (2010). Getting to Know the Y Generation. In Benckendorff, P., Moscardo, G., Pendergast, D. (Eds.), Tourism and Generation Y (pp: 1-15). Cambridge: CABI International.

Pilcher, J. (1994). Mannheim's Sociology of Generations: An Undervalued Legacy. The British Journal of Sociology. 45(3): 481-495.

Reeves, T. C. and Oh, E. J. (2007). Generation Differences and Educational Technology Research. In J. M. Spector, M. D. Merrill, J. J. G. van Merriënboer, \& M. Driscoll (Eds.), Handbook of Research 
on Educational Communications and Technology (p. 295-303). Mahwah, NJ: Lawrence Erlbaum Associates.

Robinson, M. V. and Schänzel, H. A. (2019). A Tourism Inflex: Generation Z Travel Experiences, Journal of Tourism Futures. 5 (2): 127-141.

Rundle-Thiele, S., Kubacki, K., Tkaczynski, A. and Parkinson, J. (2015). Using Two-Step Cluster Analysis to Identify Homogeneous Physical Activity Groups. Marketing Intelligence \& Planning, 33(4), 522-537.

Sá, A. M. N. C. S. (2017). Hotel Management and The Generational Impact of Millennials and iGen, Escola Superior de Hotelaria e Turismo do Estoril, Unpublished Master Thesis, Hotel Management, Portugal.

Sapnas, K. G. and Zeller, R. A. (2002). Minimizing Sample Size When Using Exploratory Factor Analysis For Measurement. Journal of Nursing Measurement, 10 (2), 135-154.

Sarı, E. ve Harta, G. (2018). Kuşakların Tüketim ve Satın Alma Davranışları Üzerine Bir Araştırma, Uluslararası Sosyal Araştırmalar Dergisi, 11(61), 967-980.

Sarıoğlu, E. B. ve Özgen, E. (2018). Z Kuşağının Sosyal Medya Kullanım Alışkanlıkları Üzerine Bir Çalışma, Uluslararası Sosyal Araştırmalar Dergisi, 11(60), 1067-1081.

Schewe, D. C. and Meredith, G. (2004). Segmenting Global Markets by Generational Cohorts: Determining Motivations by Age. Journal of Consumer Behaviour, 4(1): 51-63.

Setiawan, B., Trisdyani, P. L. N., Adnyana, P. P., Adnyana, N. I., Wiweka, K. and Wulandani, R. H. (2018). The Profile and Behaviour of 'Digital Tourists' When Making Decisions Concerning Travelling Case Study: Generation Z in South Jakarta, Advances in Research, 17(2): 1-13.

Sima, C. (2016). Generations BB, X, Y, Z, $\alpha$ - The Changing Consumer in The Hospitality Industry, In M. Ivanovap, S. Ivanov \& V. P. Magnini (Eds.), The Routledge Handbook of Hotel Chain Management (pp. 471-479). UK: Routledge Taylor \& Francis Group.

Stillman, D. and Stillman, J. (2018). İşte Z Kuşağı. 1. Basım. (Çeviren: Kayıhan, D. P. ve Erduran, F.) İstanbul: İstanbul Kültür Üniversitesi.

Strauss, W. and Howe, N. (1991). Generations: The History of America's Future, 1584 to 2069. New York, USA: William Morrow \& Company.

Streiner, D. L. (1994). Figuring Out Factors: The Use and Misuse of Factor Analysis. Canadian Journal of Psychiatry, 39, 135-140.

Tabachnick, B. G. and Fidell, L. S. (2019). Using Multivariate Statistics. Boston, MA: Pearson Education.

Tavares, M. J., Sawant, M. S. and Ban, O. (2018). A Study of The Travel Preferences of Generation Z Located in Belo Horizonte (Minas Gerais-Brazil), e-Review of Tourism Research (eRTR), 15(2-3): 223-241.

Tkaczynski, A. (2017). Segmentation using two-step cluster analysis. In Segmentation in Social Marketing, Dietrich T, Rundle-Thiele S, Kubacki K. (Eds.) Springer, Singapore, 109-125.

Töröcsik, M., Szúcs, K. and Kehl, D. (2014). How Generations Think: Research on Generation Z, Acta Universitatis Sapientiae, Communicatio. 1, 23-45.

TDK, Türk Dil Kurumu. (2019). Kuşak. Güncel Türkçe Sözlük. [Online] http://www.tdk.gov.tr/index.php?option=com_gts\&arama=gts\&guid=TDK.GTS.5ce28298132e13 .27408999 [Erişim Tarihi: 20.04.2019]. 
Uslu, A., Çetinkaya, C., Özceylan, E. ve İşleyen, S. K. (2017). Organize Sanayi Bölgelerinin Hiyerarşik-K-Ortalamalar Yöntemi ile Analizi, Türk Sosyal Bilimler Araştırmaları Dergisi, 2(1), 2037.

Venter, D., Makwela, M. and Johnson, E. H. (2015). Enhancing Visitor Awareness and Experience to The South African Armour Museum through eMarketing and New Media. [Electronic-Open Access] African Journal of Hospitality, Tourism and Leisure, 4(1): 1-15.

Williams, K. C. and Page, R. A. (2011). Marketing to The Generations. Journal of Behavioral Studies in Business, 3(1): 37-53.

Wiastuti, R. D., Lestari, N. S., Bejo Mulyadi, N. and Masatip A. (2020). The generation Z characteristics and hotel choices. African Journal of Hospitality, Tourism and Leisure, 9(1): 1-14.

Wood, S. (2013). Generation $Z$ as consumers: trends and innovation. Institute for Emerging Issues: NC State University. [Online] https://iei.ncsu.edu/wpcontent/uploads/2013/01/GenZConsumers.pdf [Erişim Tarihi: 19.03.2020].

Yeoman, I., Rebecca, T. L. Y., Mars, M. and Wouters M. (2012). 2050-Tomorrow's Tourism. Bristol, Buffalo, Toronto: Channel View Publications.

Yeoman, I., Schänzel, H. and Smith, K. (2013).A Sclerosis of Demography, Journal of Vacation Marketing. 19(2): 91-103. 